\title{
PELAKSANAAN PENYIDIKAN TERHADAP PELAKU TINDAK PIDANA NARKOTIKA DI SATUAN NARKOTIKA POLRES BUKITTINGGI ${ }^{*}$
}

\author{
Failin \\ Sekolah Tinggi Ilmu Hukum Putri Maharaja Payakumbuh \\ e-mail: failin.alin87@gmail.com
}

\begin{abstract}
Drugs, on one hand are materials used in the field of medicine, health service and the development of science that on the other hand can also affects a detrimental dependency if misused or used without control and supervision. After the enactment of Law Number 35 Year 2009 Concerning Narcotics, all actions that export, import, produce, plant, store, distribute and / or use narcotics and their sanctions are regulated therein which aims to tackle and eradicate these criminal acts. The use of narcotics without strict and thorough control and supervision is very detrimental and constitutes a huge danger to the lives of people, the community, the nation, and the State as well as Indonesia's national security. When seen in Bukittinggi Police Station from year to year the number of narcotics offenders increased and overall the case documents already complete (P21). The investigation of narcotics crime in Bukittinggi Police has been running according to the rules, which is based on the Criminal Procedural Law, however the implementation has not been effective because there are remain obstacles in the implementation of investigation.
\end{abstract}

Keywords: Investigation; Perpetrators; Criminal Acts; Narcotics.

\begin{abstract}
Abstrak
Narkoba disatu sisi merupakan obat atau bahan yang dimanfaatkan di bidang pengobatan atau pelayanan kesehatan dan pengembangan ilmu pengetahuan dan di sisi lain dapat pula menimbulkan ketergantungan yang sangat merugikan apabila disalahgunakan atau digunakan tanpa pengendalian dan pengawasan yang ketat dan seksama. Dengan lahirnya Undang-Undang Nomor 35 Tahun 2009 Tentang Narkotika, segala sesuatu tindakan yang mengekspor, mengimpor, memproduksi, menanam, menyimpan, mengedarkan dan atau menggunakan narkotika beserta sanksinya telah diatur di dalamnya yang bertujuan untuk menanggulangi dan memberantas tindak pidana tersebut. Penggunaan narkotika tanpa pengendalian dan pengawasan yang ketat dan seksama sangat merugikan dan merupakan bahaya yang sangat besar bagi kehidupan manusia, masyarakat, bangsa, dan Negara serta ketahanan nasional Indonesia. Apabila dilihat di Polres Bukittinggi dari tahun ke tahun angka pelaku tindak pidana narkotika meningkat, secara keseluruhan kasus tersebut sampai di tingkat P 21. Jadi pelaksanaan penyidikan terhadap tindak pidana narkotika di Polres Bukittinggi saat ini sudah berjalan sesuai dengan aturan, yaitu berdasarkan KUHAP, tetapi pelaksanaannya belum efektif karena dalam hal ini masih ditemukan faktor-faktor penghambat terhadap pelaksanaan penyidikannya, sehingga tidak terlaksananya pelaksanaan penyidikan yang efektif.
\end{abstract}

Kata Kunci: Penyidikan; Pelaku; Tindak Pidana; Narkotika.

\footnotetext{
* Naskah diterima: 18 Februari 2020, direvisi: 19 Maret 2020, disetujui untuk terbit: 26 Maret 2019

Doi: $10.3376 /$ jch.v5i2.232
} 
Failin: Pelaksanaan Penyidikan Terhadap Pelaku Tindak Pidana Narkotika Di Satuan...

\section{PENDAHULUAN}

Setiap individu dalam kehidupan bermasyarakat segala tingkah lakunya diatur oleh hukum, baik hukum adat di daerahnya maupun hukum yang telah diciptakan pemerintah. Sebagai patokan, hukum dapat menciptakan ketertiban dan kedamaian dalam kehidupan bermasyarakat. Hal ini sejalan dengan tujuan nasional yang termaktub dalam Pembukaan Undang-Undang Dasar 1945 yaitu melindungi segenap bangsa Indonesia dan seluruh tumpah darah Indonesia dan memajukan kesejahteraan umum, mencerdaskan kehidupan bangsa dan ikut melaksanakan ketertiban dunia yang berdasarkan kemerdekaan, perdamaian abadi dan keadilan sosial. (Aris Leonardi, Uning Pratimaratri, Fitriati Fitriati, 2013)

Perkembangan penggunaan narkotika pada saat ini tidak hanya untuk bidang kesehatan dan ilmu pengetahuan serta teknologi saja, tetapi sudah bergeser kepada tujuan untuk mencari keuntungan yang besar. Padahal Undang-Undang Nomor 35 Tahun 2009 Tentang Narkotika memuat sanksi yang cukup berat mulai dari pidana denda, penjara seumur hidup bahkan sampai pidana mati. Pidana mati adalah upaya yang radikal untuk meniadakan orang-orang yang tidak dapat diperbaiki lagi. (Andi Hamzah, 1994: 27).

Peranan hukum dalam pembangunan bangsa akan membawa konsekuensi terjadinya proses perubahan dan pembaharuan pranata yang ada, termasuk fungsi hukum dan dalam pelaksanaan kebijakan pembangunan bangsa.
Indonesia adalah negara hukum pada hakikatnya hukum berfungsi sebagai pelindung manusia agar kepentingan manusia terlindungi, hukum harus dilaksanakan. Pelaksanaan hukum itu dapat terjadi secara normal, tetapi juga dapat terjadi karena pelanggaran hukum. (Ediwarman, 2014). Setiap warga negara wajib menjunjung hukum. Kenyataan sehari-hari, warga negara yang lalai atau sengaja tidak melaksanakan kewajibannya sehingga merugikan masyarakat, dikatakan bahwa warga negara tersebut melanggar hukum karena kewajiban tersebut telah ditentukan berdasarkan hukum. (Leden Marpaung, 201: 22).

Narkoba memiliki banyak dampak negatif bagi para pengguna dan masyarakat disekitarnya. Dampak dari penggunaan narkoba yang berlebihan akan menimbulkan halusinasi, akan merasakan bahagia yang berlebihan, depresi, dan jika mengkonsumsinya secara ketergantungan akan merusak semua organ dalam tubuh dan fungsi syaraf menurun. Jika pengguna narkoba yang sudah ketergantungan atau sedang sakaw dan tidak mendapatkan narkoba, maka pengguna tersebut akan merasakan sakit yang menyiksa tubuhnya. Narkoba apabila dipergunakan secara tidak teratur menurut takaran/dosis akan dapat menimbulkan bahaya fisik dan mental bagi yang menggunakannya serta dapat menimbulkan ketergantungan pada pengguna itu sendiri, artinya keinginan sangat kuat yang bersifat psikologis untuk mempergunakan obat tersebut secara terus menerus karena sebab-sebab emosional. 
Masalah penyalahgunaan narkoba ini bukan saja merupakan masalah yang perlu mendapat perhatian bagi negara Indonesia, melainkan juga bagi dunia Internasional. (Maudy Pritha Amanda, Sahadi Humaedi, Meilanny Budiarti Santoso, 2017).

Penyalahgunaan atau pemakai yang dikategorikan pecandu maupun akibatakibat sosialnya, telah lama menjadi masalah serius diberbagai negara yang akhir-akhir ini cenderung kearah yang sangat membahayakan, dimana pemakai akan ketergantungan dan hidupnya akan ketergantungan oleh zat-zat narkotika. Sedemikian kompleksnya dalam kurun waktu minimal ternyata bukanlah perkara yang mudah. Selanjutnya, dibutuhkan waktu dan strategi juga guna memaksa individu agar tetap terlibat aktif dalam proses intervensi hingga ia menunjukkan tanda-tanda kesembuhan yang cukup meyakinkan. (Andri Winjaya Laksana, 2015)

$\begin{array}{rcr}\text { Sebenarnya } & \text { Pemerintah } & \text { sudah } \\ \text { memberlakukan } & \text { Undang-undang } & \text { (UU) }\end{array}$ untuk penyalahgunaan narkoba yaitu Undang-Undang Nomor 5 Tahun 1997 Tentang Psikotropika dan UndangUndang Nomor 35 Tahun 2009 Tentang Narkotika, tetapi tindak penyalahgunaan narkoba masih marak saja di masyarakat. Kalau dulu narkoba harus diimpor dari luar negeri tetapi sekarang negara Indonesia sudah menjadi salah satu produsen terbesar penghasil narkoba dan merupakan pasar yang potensial bagi produsen dan penyalur narkotika dunia. Pabrik-pabrik narkoba di Indonesia umumnya terletak di perumahanperumahan elit yang akses keluar masuk orang-orang ke perumahan itu sangat dibatasi sehingga pabrik narkoba itu sulit dipantau oleh aparat kepolisian. (Oksimana Darmawan, 2017)

Masalah penyalahgunaan narkotika di Indonesia ini semakin memprihatinkan, hal ini di sebabkan beberapa hal antara lain karena Indonesia yang terletak pada posisi di antara tiga benua dan mengingat perkembangan ilmu pengetahuan dan teknologi, maka pengaruh globalisasi yang sangat maju sasaran opini peredaran gelap. Bahaya penyalahgunaan narkoba tidak hanya terbatas pada diri pecandu, melainkan dapat membawa akibat lebih jauh lagi, yaitu gangguan terhadap tata kehidupan masyarakat yang bisa berdampak pada malapetaka runtuhnya suatu bangsa negara dan dunia. Negara yang tidak dapat menanggulangi penyalahgunaan dan peredaran gelap narkotika akan diklaim sebagai sarang kejahatan ini. Penyalahgunaan narkoba juga akan menimbulkan pergaulan bebas serta seks bebas di kalangan remaja, yang akan mengakibatkan meningkatnya angka aborsi, upaya memberantas kejahatan narkotika yang bersifat internasional tersebut dengan cara merutinkan adanya razia atau operasi barang-barang zat yang berbahaya seperti miras, obat-obatan.

Jika di Indonesia ini semakin banyak penggunaan narkotika maka Indonesia atau dunia ini akan hancur di jajah lagi dengan para pecandu narkoba, maka kita yang belum pernah mencoba harus cepat 
Failin: Pelaksanaan Penyidikan Terhadap Pelaku Tindak Pidana Narkotika Di Satuan...

mengatasi masalah serius ini agar dunia kita ini maju (Bakhtiar, 2019)

Hukum merupakan suatu norma/kaidah yang memuat aturan-aturan dan ketentuan-ketentuan yang menjamin hak dan kewajiban perorangan maupun masyarakat. Dengan adanya hukum dimaksudkan untuk menciptakan keselarasan hidup bermasyarakat, berbangsa dan bernegara. Memelihara keselarasan hidup di dalam masyarakat memerlukan berbagai macam aturan sebagai pedoman hubungan kepentingan perorangan maupun kepentingan dalam masyarakat. Akan tetapi tidak sedikit hubungan kepentingan itu mengakibatkan pertentangan, dalam hal ini yang berhubungan atau dalam lingkup hukum pidana. Oleh karena itu diperlukan suatu hukum acara pidana yang menjadi saluran untuk menyelesaikan kepentingan apabila terjadi perbuatan melawan hukum yang diatur dalam hukum pidana. (Bambang Poernomo, 1986: 3).

Oleh Satjipto Rahardjo sebagai penegakan hukum (Law Enforceman) dan pemulihan ketertiban (Order maintenance). Penegakan hukum merupakan suatu proses untuk mewujudkan keinginan-keinginan dalam hukum agar menjadi kewajiban dan ditaati oleh masyarakat. (Satjipto Rahardjo, 2010: 20)

Secara konseptual menurut Soerjono Soekanto, penegakan hukum terletak pada kegiatan menyerasikan hubungan nilainilai yang dijabarkan di dalam kaidahkaidah yang mantap dan mengejawantahkan serta sikap tindak sebagai rangkaian penjabaran nilai akhir dan untuk menciptakan, memelihara dan mempertahankan pergaulan hidup. Penegakan hukum tidak bisa terlepas dari hak asasi manusia, namun dengan adanya alat-alat paksa khusus (bijzonder dwangmiddelen) yang dimaksud alat paksa disini bukan merupakan pemaksaan fisik melainkan alat pemaksa yang sah diatur oleh ketentuan perundangundangan seperti penangkapan, penahanan dan penyitaan. (Seorjono Soekanto, 2006: 7)

Implementasi penegakan hukum pidana materiil artinya bagi pelanggar peraturan hukum harus dijatuhi pidana, dan untuk keperluan tersebut maka hukum pidana formil dalam pelaksanaannya harus tetap melindungi hak-hak asasi tersangka atau terdakwa seperti yang dikehendaki oleh Undangundang, salah satunya adalah hak memperoleh bantuan hukum. Upaya untuk melindungi kepentingan masyarakat agar pelaku tindak pidana tidak membahayakan dan merugikan masyarakat banyak, maka Kitab UndangUndang Hukum Acara Pidana (selanjutnya disebut KUHAP) memberikan kewenangan bagi pihak penyidik untuk menghentikan kebebasan dan kemerdekaan tersangka atau terdakwa dalam bentuk penahanan. Namun juga KUHAP memberi kesempatan kepada tersangka atau terdakwa untuk didampingi penasehat hukum sejak pemeriksaan pendahuluan sampai pemeriksaan di pengadilan. (Susilo Yuwono, 1992: 46). 
Tindak pidana narkotika telah meluas dalam kehidupan masyarakat. Meluasnya tindak pidana tersebut dapat dilihat dari jumlah kasus yang terjadi, kerugian yang diderita oleh negara, maupun dari segi kualitas tindak pidana yang dilakukan secara sistematis serta ruang lingkupnya yang memasuki seluruh aspek kehidupan masyarakat. Kejahatan narkotika merupakan suatu fenomena yang kompleks yang dapat dipahami dari berbagai sisi yang berbeda. Itu sebabnya dalam keseharian kita dapat menangkap berbagai komentar tentang suatu peristiwa kejahatan yang berbeda dengan yang lain. (Wahju Muljono, 2012: 8)

Rekapitulasi Kasus Tindak Pidana Narkotika dari Tahun 2016-2019 di Satuan Narkotika Polres Bukittinggi:

\begin{tabular}{clccc}
\hline \multirow{2}{*}{ No. } & \multicolumn{4}{c}{ Tahun } \\
& 2016 & 2017 & 2018 & 2019 \\
\hline 1. & 46 Kasus & 48 Kasus & 62 Kasus & 70 Kasus \\
\hline
\end{tabular}

Dari tabel diatas menggambarkan bahwa dari tahun ke tahun angka pelaku tindak pidana narkotika meningkat, secara keseluruhan kasus tersebut sampai di tingkat P 21. Jadi pelaksanaan penyidikan terhadap tindak pidana narkotika di Polres Bukittinggi saat ini sudah berjalan sesuai dengan aturan, yaitu berdasarkan KUHAP, tetapi pelaksanaannya belum efektif karena dalam hal ini masih ditemukan faktor-faktor penghambat terhadap pelaksanaan penyidikannya, sehingga tidak terlaksananya pelaksanaan penyidikan yang efektif.

\section{METODE PENELITIAN}

Berkaitan dengan penulisan karya ilmiah ini, penulis menggunakan pendekatan penelitian yuridis empiris yaitu penelitian yang menguji efektifitas hukum dalam pelaksanaannya di lapangan. Penulisan ini menggunakan cara studi lapangan (Empirical Research) studi lapangan yang dilakukan dalam rencana penelitian ini adalah upaya untuk mencari, menemukan dan mengumpulkan data-data yang bersifat primer. Dalam hal ini penulis akan melakukan usaha untuk memperoleh data-data yang dimaksud dengan cara menyelenggarakan tanya jawab (wawancara) bersama para narasumber diantaranya penyidik, penyidik pembantu dan pelaku tindak pidana narkotika. Analisis data yang dipergunakan dalam penelitian ini adalah analisis kualitatif dan penarikan kesimpulan dilakukan dengan metode induktif, yaitu menguraikan hal-hal yang bersifat khusus lalu menarik kesimpulan yang bersifat umum sesuai dengan permasalahan yang dibahas dalam penelitian.

\section{HASIL DAN PEMBAHASAN}

\section{Pelaksanaan Penyidikan Terhadap Pelaku Tindak Pidana Narkotika Di Satuan Narkotika Polres Bukittinggi}

Berdasarkan hasil wawancara penulis dengan IPTU Amril, SH yaitu Kepala Kaur Bin Ops narkoba pada hari Senin tanggal 10 Februari 2020 bahwa pelaksanaan penyidikan terhadap tindak pidana narkotika yang dilakukan oleh aparat penyidik di Polres Bukittinggi 
Failin: Pelaksanaan Penyidikan Terhadap Pelaku Tindak Pidana Narkotika Di Satuan...

terhadap tersangka, telah sesuai dengan Undang-Undang yang berlaku, diantaranya: Kitab Undang-Undang Hukum Acara Pidana, Undang-Undang Nomor 2 Tahun 2002 Tentang Kepolisian Negara Republik Indonesia, dan Peraturan Pemerintah RI Nomor 27 Tahun 1983 Tentang Pelaksanaan KUHAP, tetapi belum efektif karena dalam pelaksanaan masih ditemukan beberapa faktor penyebab tidak terlaksananya pelaksanaan penyidikan.

Adapun pelaksanaan penyidikan yang dilakukan oleh Unit Reserse Narkoba dalam mengungkap pelaku tindak pidana narkotika adalah sebagai berikut: setelah penyidik menerima laporan informasi dari masyarakat maka dilakukanlah penyelidikan. Adapun tindakan-tindakan yang dilakukan penyidik Unit Reserse Narkoba dalam mengungkap pelaku tindak pidana narkotika adalah sebagai berikut:

1. Penyelidikan terhadap seseorang pelaku tindak pidana narkotika.

2. Dilakukan penangkapan.

3. Dilakukan penggeledahan.

4. Penyitaan terhadap barang bukti.

5. Mengumpulkan saksi-saksi.

6. Membuat laporan polisi.

7. Meminta status sita kepada kejaksaan.

8. Melakukan penimbangan barang bukti kepada puslabfor/instansi lain yang mempunyai badan hukum.

9. Melakukan cek urine terhadap tersangka dirumah sakit.

10. Melakukan penahanan/membuat sprinhan.
11. Mengirimkan barang bukti ke puslabfor medan.

12. Melakukan pemeriksaan/BAP terhadap tersangka dan saksi.

13. Setelah dianggap lengkap berkas lalu dikirimkan kepada kejaksaan (tahap 1).

14. Apabila berkas dianggap ada yang kurang dari kejaksaan maka berkas akan dikembalikan kepada penyidik.

15. Setelah berkas dilengkapi oleh penyidik maka berkas diserahkan kembali kepada kejaksaan.

16. Setelah berkas dianggap lengkap oleh kejaksaan maka penyidik menerima P21 dari kejaksaan (berkas dianggap lengkap oleh kejaksaan).

17. Penyidik melakukan penyerahan barang bukti dan tersangka (tahap 2) kepada kejaksaan.

Pelaksanaan penyidikan terhadap pelaku tindak pidana narkotika oleh pihak Polres Bukittinggi adalah suatu sistem atau cara penyidikan yang dilakukan untuk mencari, serta mengumpulkan bukti yang dengan bukti itu membuat terang tindak pidana yang terjadi dan guna menemukan tersangkanya sesuai dengan cara yang diatur dalam KUHAP.

Penyelidikan sendiri sangat berguna untuk hakim menentukan pemidanaan proses pemidanaan dilaksanakan oleh aparat penegak hukum dari tahap penyelidikan sampai pada tahap eksekusi. Setelah penyidikan maka dilakukanlah proses penuntutan yang dilakukan oleh jaksa penuntut umum dimana jaksa penuntut umum dalam melakukan 
penuntutan dengan cara melakukan pembuktian melalui alat bukti. Setelah pembuktian dilakukan oleh jaksa penuntut umum maka hakim dapat menentukan maka hakim dapat berfikir apabila hakim telah mendapat keyakinan dari minimal dua alat bukti yang sah akan kebenaran dari perkara tersebut maka hakim dapat mempertimbangkan hukuman apa yang akan dijatuhkan. (Siti Soetami, 1998: 67).

Penegakan hukum yang paling diutamakan di Indonesia adalah penegakan hukum secara pidana dimana pidana mengatur melarang dan memberikan sanksi terhadap pelaku hukum, penegakan hukum secara pidana ini diharapkan mampu sebagai faktor penangkal terhadap merebaknya peredaran perdagangan narkotika, tapi dalam kenyataannya justru semakin intensif penegakan hukum semakin meningkat pula peredaran perdagangan narkotika dan psikotropika tersebut yang berarti perlu adanya perhatian khusus pada tindak pidana narkotika.

Penegakan hukum menurut Liliana Tedjosaputro adalah suatu proses untuk mewujudkan keinginan-keinginan hukum menjadi kenyataan. Keinginan-keinginan hukum di sini adalah pikiran-pikiran badan pembuat Undang-undang yang dirumuskan dalam peraturan perundangundangan hukum itu, dan ini akan turut menentukan bagaimana penegakan hukum itu dijalankan. (Liliana Tedjosaputro, 1995: 55)

Penegakan hukum atau penanggulangan kejahatan juga mencakup tindakan preventif dan represif terhadap kejahatan. Usaha yang menunjukkan pembinaan, pendidikan, dan penyadaran terhadap masyarakat umum sebelum terjadi gejolak perbuatan kejahatan, pada dasarnya merupakan tindakan pencegahan atau preventif. Sedangkan usaha yang menunjukkan upaya pemberantasan terhadap tindakan kejahatan yang sedang terjadi merupakan tindakan represif.

Proses pelaksanaan penyidikan terhadap pelaku penyalahgunaan narkotika di Polres Bukittinggi berjalan sesuai dengan ketentuan KUHAP. Namun, ada beberapa ketentuan penambahan alat bukti selain yang terdapat dalam KUHAP dan diinputkan dalam pasal 86 ayat (2) Undang-Undang Nomor 35 Tahun 2009 Tentang Narkotika, mengenai alat bukti sebagaimana dimaksud berupa informasi yang diucapkan, dikirimkan, diterima atau disimpan secara elektronik dengan alat optik atau yang serupa dengan itu; dan data rekaman atau informasi yang dapat dilihat, dibaca, dan /atau didengar, yang dapat dikeluarkan dengan atau tanpa bantuan suatu sarana baik yang tertuang di atas kertas, benda fisik apapun selain kertas maupun yang terekam secara elektronik, termasuk tetapi tidak terbatas pada: tulisan, suara, dan/ atau gambar; peta, rancangan, foto atau sejenisnya; atau huruf, tanda, angka, simbol, sandi, atau perforasi yang memiliki makna dapat dipahami oleh orang yang mampu membaca atau memahaminya. Apabila Satuan Reserse Narkotika mendapat informasi wajib melindungi pelapor sesuai dengan Pasal 99 Undang-Undang 
Failin: Pelaksanaan Penyidikan Terhadap Pelaku Tindak Pidana Narkotika Di Satuan...

Nomor 35 Tahun 2009 Tentang Narkotika, sehingga dari sumber informasi masyarakat terdapat unsur bukti permulaan cukup, maka penyidik sesuai amanat pasal 103 KUHAP yaitu apabila laporan atau pengaduan yang diajukan secara tertulis harus ditandatangani oleh pelapor atau pengadu.

2. Kendala yang dihadapi dalam Pelaksanaan Penyidikan Terhadap Pelaku Tindak Pidana Narkotika Di Satuan Narkotika Polres Bukittinggi

Kendala dalam melakukan penyidikan terhadap tersangka tindak pidana narkoba berdasarkan UndangUndang Nomor 8 Tahun 1981 Tentang Hukum Acara Pidana di Polres Bukittinggi adalah:

1. Pengiriman berkas perkara ke Jaksa penuntut atau dikenal dengan Tahap I sering terlambat bahkan habis masa penahanan.

2. Adanya komplain dari pihak tersangka terhadap penyidik Polri karena keterlambatan dan kepastian status tersangka di tingkat penyidikan.

3. Sumber daya manusia. Bahwa penyidik dan penyidik pembantu yang ditempatkan di Direktorat Reserse Narkoba Polres Bukittinggi masih banyak yang belum memenuhi persyaratan, antara lain:

a. Tidak pernah melaksanakan pelatihan atau kejuruan tentang penyidikan tindak pidana apalagi tindak pidana narkoba.

b. Pemahaman tugas pokok (integritas) masih kurang dalam menyidik kasus tindak pidana narkoba.

c. Karena kurangnya pemahaman tentang penyidikan, penyidik dan penyidik pembantu tidak memikirkan resiko yang timbul dalam kesalahan penyidikan tersebut.

4. Sarana dan prasarana dalam penyidikan masih kurang, antara lain:

a. Komputer

Dalam pengerjaan administrasi penyidikan sering terlambat dalam pengerjaannya, bahkan rata-rata personil mengadakan sendiri.

b. Anggaran

Dalam kegiatan penyidikan, anggaran sangat terbatas sehingga anggota sering apatis dalam penyidikan, resikonya kasus terbengkalai.

c. Transportasi

Transpotasi dalam penyidikan masih kurang, sehingga penyelesaian administrasi penyidikan sering terlambat karena jarak tempuh untuk melakukan penetapan status barang bukti, penetapan penyitaan, dan administrasi lainnya sering terlambat.

5. Uji barang bukti

Uji laboratorium kriminal terhadap sampel barang bukti berbagai jenis narkoba dan sampel bukti elektronik dilaksanakan diluar daerah. Untuk uji laboratorium Polres Bukittinggi dilaksanakan di Polda Sumatera Utara.

Pada prinsipnya selain itu adalah dalam uji laboratorium ini di samping jauh, laboratorium kriminal yang ada di Polda Sumatera Utara juga melayani daerah lainnya, diantaranya Polda Aceh, Sumatera Utara, Riau Kepulauan, dan 
Sumatera Barat. Sehingga layanan untuk pengujian terlalu banyak, sehingga waktu yang diberikan dalam Undang-Undang Nomor 35 Tahun 2009, waktu penangkapan diberikan $3 \times 24$ jam dan dapat diperpanjang $3 \times 24$ jam (6 hari) sering molor atau lewat batas waktu 6 hari. Kalau penyidik mengeluarkan surat perintah penahanan, akan berakibat ketidakpastian dalam penahanan, karena hasil belum jelas positif atau negatif narkoba, hal ini bisa terjadi kesalahan oleh penyidik. Jika hasilnya negatif, penyidik akan keliru dalam menerbitkan surat perintah penahanan.

Kesulitan dalam mengungkapkan kasus tersebut, karena antara pembeli dan penjual menggunakan sistem putus atau tidak bertemu langsung. Segala transaksi yang dilakukan oleh pembeli dan penjual narkotika semuanya tanpa mengenali satu sama lainnya. Ketika seseorang mendapatkan barang narkotika tersebut belum tentu dia tahu dan kenal siapa yang diajak transaksinya. Begitu juga dengan masyarakat karena sulit untuk dimintai keterangan atau informasi, terkadang warga masyarakat menjawab tidak tahu atau malah mengatakan untuk minta keterangan ke pihak ketua RT atau pihak keamanan.

Demi kepentingan bangsa dan negara, peneliti berharap kepada seluruh lapisan masyarakat untuk tidak takut ataupun merasa ragu memberikan keterangan kepada pihak Penegak Hukum, apabila mempunyai informasi mengenai tindak pidana, khususnya tindak pidana penyalahgunaan narkotika.
Pemberi informasi tidak perlu merasa takut ataupun khawatir, karena pihak penegak hukum akan melindunginya dari ancaman-ancaman atau kejadian yang tidak diinginkan.

Hambatan yang dihadapi oleh Penyidik Polres Bukittinggi dalam melakukan proses penyidikan terhadap pelaku penyalahgunaan narkotika yaitu partisipasi masyarakat walaupun sudah ada partisipasi untuk memberikan informasi telah terjadi tindak pidana penyalahgunaan narkotika, namun masih dirasa kurang dan perlu untuk ditingkatkan peran sertanya, selain yang disebutkan di atas, adalah mengenai penyelidikan yang kadang mengalami kesulitan karena jaringan dari tindak pidana penyalahgunaan narkotika yang mudah terputus mata rantainya.

Pihak Satuan Narkotika Polres Bukittinggi berharap bahwa dengan instrument Pasal 131 Undang-Undang Nomor 35 Tahun 2009 Tentang Narkotika, diharapkan partisipasi masyarakat untuk memberikan informasi pengaduan terjadinya tindak pidana narkotika di Polres Bukittinggi dapat makin meningkat. Dalam Pasal 131 Undang-Undang Nomor 35 Tahun 2009 Tentang Narkotika disebutkan bahwa:

"Setiap orang yang ia mengetahui telah terjadi tindak pidana penyalahgunaan narkotika namun ia tidak melapor maka dapat dikenai suatu ketentuan pidana paling lama 1 (satu) tahun dan denda 50 juta rupiah".

Hambatan selain yang disebutkan di atas, adalah mengenai penyelidikan yang 
Failin: Pelaksanaan Penyidikan Terhadap Pelaku Tindak Pidana Narkotika Di Satuan...

kadang mengalami kesulitan karena jaringan dari tindak pidana penyalahgunaan narkotika yang mudah terputus mata rantainya. Jadi, dibutuhkan kejelian dari aparat penegak hukum dalam memberantas jaringan narkotika sampai ke akar-akarnya. Untuk fasilitas kendaraan transportasi bagi penyidik Satuan Narkotika Polres Bukittinggi juga dirasa sedikit menghambat karena kadang masih kurang dana operasionalnya walaupun mengenai penyediaan fasilitas kendaraan bagi aparat penyidik Satuan Narkotika dilakukan secara prioritas. Dibutuhkan peralatan-peralatan IT (Informasi Teknologi) yang lebih canggih lagi dalam mengungkap jaringan narkotika yang selama ini sudah menggunakan teknologi canggih juga.

\section{Upaya yang Dilakukan Dalam Menghadapi Kendala Pelaksanaan Penyidikan Terhadap Pelaku Tindak Pidana Narkotika Di Satuan Narkotika Polres Bukittinggi}

Upaya penyidik dalam mengatasi faktor-faktor penghambat dalam pelaksanaan penyidikan kasus-kasus narkoba untuk menghindari kesalahankesalahan dalam hukum acara pidana:

1. Penyidik melakukan pelatihan atau pemahaman-pemahaman terhadap penyidik pembantu tentang penanganan tindak pidana narkoba dan melatih sendiri terhadap penyidik pembantu tentang tugas-tugas dalam administrasi penyidikan guna meminimalisir komplain dari pihak tersangka.
2. Pengawasan dan pemeriksaan setiap kegiatan dan lembaran kerja administrasi yang dibuat oleh penyidik pembantu.

3. Tentang kemampuan penyidik dan penyidik pembantu, sumber daya manusia yang masih kurang yang ditempatkan di unit-unit kerja dicampur, jika penyidik mahir ditempatkan penyidik pembantu yang perlu bimbingan dalam penyidikan dan sebaliknya jika penyidik pembantu mahir ditempatkan di penyidik yang kurang mahir.

4. Kekurangan anggaran dan alat transpotasi diajukan pada anggaran tahun berikutnya, akan tetapi pengajuan tersebut jarang terealisasi.

5. Dalam uji coba laboratorium kriminal, penyidik melakukan koordinasi sejak diserahkan barang bukti narkoba tentang hasil pemeriksaan terhadap petugas laboratorium.

Upaya-upaya yang dilakukan Polri dalam memecahkan hambatan-hambatan dalam penyidikan tindak pidana narkoba. Tindak pidana Narkoba sebagai tindak pidana yang tidak hanya membahayakan pelakunya tetapi juga bangsa dan negara haruslah dapat dilakukan pencegahan. Polri sebagai aparat penegak hukum tidak terlepas dari hambatan-hambatan dalam penyelidikan tindak pidana narkoba.

Untuk itu diperlukan upaya untuk memecahkan hambatan-hambatan penyidikan tindak pidana narkoba seperti dalam uraian sebelumnya:

a. Latihan rutin sebagai alternatif untuk mengatasi kekurangan pendidikan 
khusus mengenai penyidikan narkoba.

b. Penyuluhan yang dilakukan Polri sebagai upaya penanggulangan preventif tindak pidana narkoba.

Demi kepentingan bangsa dan negara, peneliti berharap kepada seluruh lapisan masyarakat untuk tidak takut ataupun merasa ragu memberikan keterangan kepada pihak Penegak Hukum, apabila mempunyai informasi mengenai tindak pidana, khususnya tindak pidana penyalahgunaan narkotika. Pemberi informasi tidak perlu merasa takut ataupun khawatir karena pihak penegak hukum akan melindunginya dari ancaman-ancaman atau kejadian yang tidak diinginkan.

Salah satu upaya yang dilakukan adalah dengan hadirnya Badan Narkotika Nasional tentunya akan menjadi duet mechanism terhadap penegak hukum tindak pidana narkotika bersama dengan lembaga kepolisian bahkan di samping itu masih ada penyidik lainnya yakni penyidik pegawai negeri sipil. Badan Narkotika Nasional diberi wewenang melakukan penyidikan terhadap tindak pidana narkotika di samping dapat juga dilakukan penyidik Kepolisian Republik Indonesia. Keduanya harus saling berkoordinasi dan saling memberitahu apabila telah memulai melakukan penyidikan terhadap tindak pidana narkotika. Meskipun keduanya harus saling berkoordinasi tetapi telah memberi sinyalemen atau petunjuk tentang ketidakmampuan (inability) dari kepolisian dalam menjalankan tugas dan wewenangnya dalam melakukan pengusutan terhadap tindak pidana narkotika dengan baik.

Sedangkan penyidik pegawai negeri sipil posisinya juga penyidik yang diberikan kewenangan oleh UndangUndang Nomor 35 Tahun 2009 tentang Narkotika namun selaku koordinator dan pengawas tetap berada di pihak Kepolisian Republik Indonesia sebagaimana telah digariskan Pasal 7 ayat (2) Undang-Undang Nomor 8 Tahun 1981 Tentang Hukum Acara Pidana.

Kewenangan Badan Narkotika Nasional yang terlalu besar seperti dalam penahanan dan penggeledahan menurut Undang-Undang Nomor 35 Tahun 2009 Tentang Narkotika ternyata tidak sama dengan kewenangan yang diberikan kepada penyidik polisi dan penyidik pegawai negeri sipil. Perbedaan ini berpotensi menimbulkan permasalahan secara kelembagaan serta egoisme institusional diantara lembaga penegak hukum.

Permasalahan kewenangan dapat menjadi polemik institusional yang patut menjadi perhatian. Kewenangan menyangkut masalah integritas institusional dan selalu terjadi upaya pencegahan-pencegahan terhadap pengurangan kekuasaan. Pengurangan kekuasaan dapat menimbulkan sikap persepsi keliru dari institusi yang menerima pengurangan tersebut. Institusi dapat dianggap tidak mampu dan tidak cakap melaksanakan kekuasaan yang diberikan oleh Undang-undang bahkan dianggap tidak pernah memberikan 
Failin: Pelaksanaan Penyidikan Terhadap Pelaku Tindak Pidana Narkotika Di Satuan...

akuntabilitas memadai sesuai dengan harapan masyarakat apalagi kewenangan ini menyangkut kekuasaan. Ibarat the elimination of power is a show of power akibatnya yang timbul adalah arogansi institusional sekaligus egoisme struktural sehingga akan mengganggu proses penegakan hukum pada tindak pidana narkotika secara komprehensif.

(Beniharmoni Harefa, 2017)

Kewenangan Penyidikan Badan Narkotika Nasional berdasarkan UndangUndang Nomor 35 Tahun 2009 Tentang Narkotika. Diatur dalam Pasal 75 dan Pasal 80 Undang-Undang Nomor 35 Tahun 2009 Tentang Narkotika. Adapun Pasal 75 berbunyi sebagai berikut: Dalam rangka melakukan penyidikan, penyidik BNN berwenang:

1. Melakukan penyelidikan atas kebenaran laporan serta keterangan tentang adanya penyalahgunaan dan peredaran gelap Narkotika dan Prekursor Narkotika;

2. Memeriksa orang atau korporasi yang diduga melakukan penyalahgunaan dan peredaran gelap Narkotika dan Prekursor Narkotika;

3. Memanggil orang untuk didengar keterangannya sebagai saksi;

4. Menyuruh berhenti orang yang diduga melakukan penyalahgunaan dan peredaran gelap Narkotika dan Prekursor Narkotika serta memeriksa tanda pengenal diri tersangka;

5. Memeriksa, menggeledah, dan menyita barang bukti tindak pidana dalam penyalahgunaan dan peredaran gelap Narkotika dan Prekursor Narkotika;

6. Memeriksa surat dan/atau dokumen lain tentang penyalahgunaan dan peredaran gelap Narkotika dan Prekursor Narkotika;

7. Menangkap dan menahan orang yang diduga melakukan penyalahgunaan dan peredaran gelap Narkotika dan Prekursor Narkotika;

8. Melakukan interdiksi terhadap peredaran gelap Narkotika dan Prekursor Narkotika di seluruh wilayah juridiksi nasional;

9. Melakukan penyadapan yang terkait dengan penyalahgunaan dan peredaran gelap Narkotika dan Prekursor Narkotika setelah terdapat bukti awal yang cukup;

10. Melakukan teknik penyidikan pembelian terselubung dan penyerahan di bawah pengawasan;

11. Memusnahkan Narkotika dan Prekursor Narkotika;

12. Melakukan tes urine, tes darah, tes rambut, tes asam dioksiribonukleat (DNA), dan/atau tes bagian tubuh lainnya;

13. Mengambil sidik jari dan memotret tersangka;

14. Melakukan pemindaian terhadap orang, barang, binatang, dan tanaman;

15. Membuka dan memeriksa setiap barang kiriman melalui pos dan alat-alat perhubungan lainnya yang diduga mempunyai hubungan dengan penyalahgunaan dan peredaran 
gelap Narkotika dan Prekursor Narkotika;

16. Melakukan penyegelan terhadap Narkotika dan Prekursor Narkotika yang disita;

17. Melakukan uji laboratorium terhadap sampel dan barang bukti Narkotika dan Prekursor Narkotika;

18. Meminta bantuan tenaga ahli yang diperlukan dalam hubungannya dengan tugas penyidikan penyalahgunaan dan peredaran gelap Narkotika dan Prekursor

19. Menghentikan penyidikan apabila tidak cukup bukti adanya dugaan penyalahgunaan dan peredaran gelap Narkotika dan Prekursor Narkotika.

Dalam upaya penanggulangan tindak pidana narkotika maka Polres Bukittinggi melakukan hal-hal sebagai berikut:

1. Upaya preventif

Upaya preventif adalah sebuah upaya yang dilakukan oleh Polres Bukittinggi dan dilakukan sebelum penyalahgunaan terjadi dalam bentuk kampanye, penyuluhan, sosialisasi, pendekatan pada keluarga, dan penyebaran pengetahuan mengenai bahaya narkoba. Cara ini dilakukan di berbagai kelompok masyarakat seperti sekolah, dari tingkat Sekolah Dasar (SD) sampai Sekolah Menengah Atas (SMA), hingga perguruan tinggi, bahkan juga dilakukan di beberapa perkampungan wilayah Riau. Berikut ini adalah upaya yang telah dilakukan oleh Polres Bukittinggi dalam menanggulangi penyalahgunaan narkoba.
Penyalahgunaan narkoba dapat merusak perkembangan jiwa generasi muda baik bagi pengguna maupun orang lain. Narkoba sebagai zat yang sangat diperlukan untuk pengobatan dalam pelayanan kesehatan seringkali disalahgunakan tidak sesuai dengan standar pengobatan dan jika disertai peredaran narkoba secara gelap akan menimbulkan akibat yang sangat merugikan perorangan ataupun masyarakat, khususnya generasi muda, maka perlu diadakannya upaya sosialisasi terhadap generasi muda.

\section{Upaya Represif}

Polres Bukittinggi telah melakukan fungsi penegakan hukum. Peranan penegak hukum salah satunya ialah bagaimana mengaktualisasikan secara nyata, aturan-aturan hukum bisa terwujud dalam kaidah-kaidah sosial masyarakat. Sebagai suatu sarana untuk menegakkan hukum diantaranya ialah dengan penerapan sanksi pidana. Perumusan norma-norma pidana telah diatur dalam Undang-Undang Nomor 5 Tahun 1997 dan Undang-Undang Nomor 35 Tahun 2009, berikut konsep penetapan sanksi pidana. Dalam Undang-undang tersebut, untuk menentukan kategorisasi sanksi pidana lebih ditentukan oleh jenis-jenis penggolongan psikotropika dan narkotika yang dilanggar, seyogyanya pemerintah mengatur tentang batas maksimal jumlah psikotropika dan narkotika yang disimpan, digunakan, dimiliki, secara tidak sah sehingga dapat membedakan pelaku tindak pidana, apakah digolongkan sebagai pemilik, pengguna atau pengedar. 
Failin: Pelaksanaan Penyidikan Terhadap Pelaku Tindak Pidana Narkotika Di Satuan...

\section{SIMPULAN}

Berdasarkan pembahasan tersebut di atas, maka penulis menarik kesimpulan sebagai berikut:

1. Pelaksanaan penyidikan terhadap pelaku tindak pidana narkotika berdasarkan Kitab Undang-Undang Hukum Acara Pidana (KUHAP) di Satuan Narkotika Polres Bukittinggi adalah berawal dari penyelidikan terhadap seseorang pelaku tindak pidana narkotika, dilakukan penangkapan. dilakukan penggeledahan, penyitaan terhadap barang bukti, mencacat saksi-saksi, membuat laporan polisi, meminta status sita kepada kejaksaan, melakukan penimbangan barang bukti kepada puslabfor/instansi lain yang mempunyai badan hukum, melakukan cek urine terhadap tersangka di rumah sakit, melakukan penahanan/membuat sprinhan, mengirimkan barang bukti ke puslabfor medan, melakukan pemeriksaan/BAP terhadap tersangka dan saksi, setelah dianggap lengkap berkas lalu dikirimkan kepada kejaksaan (tahap 1), apabila berkas dianggap ada yang kurang dari kejaksaan maka berkas akan dikembalikan kepada penyidik, setelah berkas dilengkapi oleh penyidik maka berkas diserahkan kembali kepada kejaksaan, setelah berkas dianggap lengkap oleh kejaksaan maka penyidik menerima P21 dari kejaksaan (berkas dianggap lengkap oleh kejaksaan) dan penyidik melakukan penyerahan barang bukti dan tersangka (tahap 2) kepada kejaksaan. Namun pelaksanaannya belum efektif karena ada kendala dalam pelaksanaannya.

2. Kendala pelaksanaan penyidikan terhadap pelaku tindak pidana narkotika berdasarkan Kitab Undang-Undang Hukum Acara Pidana (KUHAP) di Satuan Narkotika Polres Bukittinggi adalah pengiriman berkas perkara ke Jaksa penuntut atau dikenal dengan Tahap I sering terlambat bahkan habis masa penahanan. Serta adanya komplain dari pihak tersangka terhadap penyidik Polri karena keterlambatan dan kepastian status tersangka di tingkat penyidikan, keterbatasan sumber daya manusia, kurangnya sarana dan prasarana yang dimiliki oleh penyidik Polres Bukittinggi dan tidak efektifnya uji laboratorium kriminal terhadap sampel barang bukti berbagai jenis narkoba dan sampel bukti elektronik dilaksanakan diluar daerah. Untuk uji laboratorium Polres Bukittinggi dilaksanakan di Polda Sumatera Utara.

3. Upaya yang dilakukan dalam mengatasi kendala pelaksanaan penyidikan terhadap pelaku tindak pidana narkotika berdasarkan Kitab Undang-Undang Hukum Acara Pidana (KUHAP) di Satuan Narkotika Polres Bukittinggi adalah dengan cara menambah pengetahuan dan kemampuan penyidik dengan cara melakukan pelatihan terhadap 
tugas dalam administrasi, dalam uji coba laboratorium kriminal, penyidik melakukan koordinasi sejak diserahkan barang bukti narkoba tentang hasil pemeriksaan terhadap petugas laboratorium. Sehingga pelaksanaan penyidikan bisa berjalan dengan efektif.

\section{DAFTAR PUSTAKA}

\section{Buku}

Andi Hamzah, dkk, 1994, Pidana Mati di Indonesia di Masa Lalu, Kini, dan Masa Depan, Ghalia Indonesia, Jakarta

Bambang Poernomo, 1986, Pokok-Pokok Tata Acara Peradilan Pidana Indonesia dalam KUHAP, Sinar Grafika, Jakarta;

Ediwarman, 2014, Penegakan Hukum dalam Perspektif Kriminologi, Genta Publishing, Yogyakarta,

Leden Marpaung, 2011, Proses Penanganan Perkara Pidana (Penyidikan dan Penyelidikan), Cetakan Ketiga, Sinar Grafika, Jakarta

Liliana Tedjosaputro, 1995, Penegakan Hukum, PT Bayu Indra Grafika, Yogyakarta

Satjipto Rahardjo, 2010, Penyelenggaraan Keadilan Dalam Masyarakat Yang Sedang Berubah, Laksbang Mediatama, Surabaya

Siti Soetami, 1998, Pengantar Hukum Indonesia, Refika Aditama, Bandung

Seorjono Soekanto, 2006, Hukum Acara Pidana, Badan Penerbit Universitas Diponegoro, Semarang
Susilo Yuwono, 1992, Penyelesaian Perkara Pidana Berdasarkan KUHAP, Sistem dan Prosedur, Penerbitan Alumni, Bandung;

Wahju Muljono, 2012, Pengantar Teori Kriminologi, Pustaka Yustisia, Yogyakarta;

\section{Jurnal}

Aris Leonardi, Uning Pratimaratri, Fitriati Fitriati, (2013). Kebijakan Hukum Pidana Dalam Penyalahgunaan Narkotika di Kalangan Remaja (Studi Kasus: Polres Rokan Hulu Provinsi Riau). Abstract of Undergraduate Research, Faculty of Law, Bung Hatta University. 3 (1), 31-40.

Maudy Pritha Amanda, Sahadi Humaedi, Meilanny Budiarti Santoso, 2017. Penyalahgunaan Narkoba di Kalangan Remaja (Adolescent Substance Abuse. Jurnal Penelitian \& PPM. 4 (2), 129 - 389.

Andri Winjaya Laksana, (2015). Tinjauan Hukum Pemidanaan Terhadap Pelaku Penyalahguna Narkotika Dengan Sistem Rehabilitasi, Jurnal Pembaharuan Hukum, 2 (1). 74-85

Bakhtiar, (2019). Kumulasi Pidana Penjara dan Denda dalam Perkara Narkotika, Kanun Jurnal Ilmu Hukum, 21 (1). 111-116

Oksimana Darmawan, (2017). Kebijakan Pemerintah Mengenai Penanganan Anak Pelaku Tindak Pidana Narkoba (Studi Kasus di Provinsi DKI Jakarta), Jurnal Hukum Mimbar Justitia, 3 (2). 177-203

$\begin{array}{ccr}\text { Beniharmoni } & \text { Harefa, } & \text { (2017). } \\ \text { Perlindungan } & \text { Hukum } & \text { Terhadap }\end{array}$ 
Failin: Pelaksanaan Penyidikan Terhadap Pelaku Tindak Pidana Narkotika Di Satuan...

Anak Sebagai Penyalahgunaan Narkotika Dalam Sistem Peradilan Pidana Anak di Indonesia, Perspektif, 22 (3). 222-230

\section{Undang-Undang}

Undang-Undang Dasar Republik Indonesia 1945

Kitab Undang-Undang Hukum Pidana
Undang-Undang Nomor 8 Tahun 1981 Tentang Hukum Acara Pidana

Undang-Undang Nomor 2 Tahun 2002 Tentang Kepolisian Negara Republik Indonesia

Undang-Undang Nomor 35 Tahun 2009 Tentang Narkotika. 